\title{
Synchronous changes of morphology and gonadal development of silvering Japanese eel Anguilla japonica
}

\author{
Yu-San Han ${ }^{\mathrm{a}}$, I-Chiu Liao ${ }^{\mathrm{b}}$, Yung-Sen Huang ${ }^{\mathrm{c}}$, Je-Tung He ${ }^{\mathrm{a}}$, \\ Chih-Wei Chang ${ }^{\mathrm{a}}$, Wann-Nian Tzeng ${ }^{\mathrm{a}, *}$ \\ ${ }^{a}$ Institute of Zoology, College of Science, National Taiwan University, Taipei 106, Taiwan, ROC \\ ${ }^{\mathrm{b}}$ Taiwan Fisheries Research Institute, 199 Hou-Ih Road, Keelung 202, Taiwan, ROC \\ ${ }^{\mathrm{c}}$ National Museum of Marine Biology and Aquarium, 2 Houwan Road, Checheng, Pingtung 994, Taiwan, ROC
}

Received 9 April 2002; received in revised form 1 October 2002; accepted 23 October 2002

\begin{abstract}
The gonadal development of Japanese eel Anguilla japonica during silvering was examined via gonadal histology and morphometric characteristics. Specimens were collected from the Kaoping River of Taiwan between November 1998 and November 2001. Female eels predominated, constituting $87.6 \%$ of the sex-determined eels. The degree of gonadal development was assessed by skin coloration, with female eels divided into yellow, pre-silver, and silver phases. Males were divided into yellow and silver phases because of small sample size. Silver phase eels predominated in the winter. Mean $( \pm$ S.E.) total length of silver-phase eels was significantly larger in females $(642.2 \pm 10.4)$ than males $(564.8 \pm 14.6)(p<0.001)$. The mean $( \pm$ S.E. $)$ gonadosomatic index (GSI) of females increased significantly from $0.27 \pm 0.01$ for yellow phase, to $0.55 \pm 0.03$ for presilver and $1.32 \pm 0.07$ for silver phase. Oocyte development progressed from the chromatin nucleolus stage in the yellow phase eel, through the peri-nucleolus stage in the pre-silver phase eel and to the oil-drop stage in the silver phase eel. Spermatogenesis was active for silver phase males which had a larger mean GSI $(0.15 \pm 0.01)$ than yellow phase males $(0.07 \pm 0.02)$, but the gonadal development of males was slower than that of females. GSI, ocular index (OI), and fin-index (FI) were positively correlated, and gut-index (GI) was negatively correlated with total length in both sexes. Residual analysis of the regression of the indices GSI, OI, FI, and GI on TL indicated that the variation of the indices with growth was greatly influenced by the developmental phase of the eel. On the other hand, OI and FI were positively correlated and GI was negatively correlated with GSI,
\end{abstract}

* Corresponding author. Tel.: +886-2-23639570; fax: +886-2-23636837.

E-mail address: wnt@ccms.ntu.edu.tw (W.-N. Tzeng). 
irrespective of eel phases. These results suggested that the skin coloration, OI, and FI were reliable criteria in selecting mature eel brooders for artificial propagation purposes.

(C) 2003 Elsevier Science B.V. All rights reserved.

Keywords: Japanese eel; Anguilla japonica; Silvering; Gonadal development; Morphology

\section{Introduction}

The Japanese eel, Anguilla japonica Temminck and Schlegel, is a catadromous fish (Ege, 1939). It spawns in the tropical Pacific Ocean west of the Mariana Islands (Tsukamoto, 1992; Liao et al., 1996, 1999). After hatching, the leptocephali are transported by the North Equatorial Current and Kuroshio Current from the spawning ground to the continental shelf of Taiwan, China, Korea, and Japan. They metamorphose into glass eels in the coastal waters and become pigmented elvers in the estuary (Ege, 1939; Tesch, 1977). The elvers become yellow eels in rivers where they may live for 5-8 years until maturation (Tzeng et al., 2000). At the onset of maturation, the yellow eels metamorphose into silver eels (also known as "silvering") and migrate back to the spawning area to spawn and die (Tesch, 1977).

Since Yamamoto and Yamauchi (1974) successfully hatched the first eel larva in 1973, the larvae have not yet been successfully developed into glass eels. Elvers for aquaculture are still caught from estuaries (Tzeng, 1985). However, the supply of wild elvers is insufficient to meet the demand for aquaculture (Tzeng, 1996). Thus, artificial propagation is an urgent requirement for the aquaculture industry. Ijiri et al. (1998) indicated that the wild silver eel is a better candidate for artificial maturation than feminized or cultured eels because of the better development of the gonads. Thus, it is essential to establish criteria based upon external morphology for the selection of the more mature silver eels.

During silvering, the eel eye size, snout, pectoral fins, digestive tract, and liver weight all undergo change (Matsui, 1958, 1972; Tesch, 1977; Pankhurst, 1982; Pankhurst and Sorensen, 1984; Jessop, 1987; Sorensen and Pankhurst, 1988). Skin color also changes from white/yellow to silver on the belly and from green to black on the back. These changes are thought to be a pre-adaptation to the marine environment for spawning migration (Pankhurst, 1982; Fontaine et al., 1995), and are believed to relate to gonadal development (Waring, 1963; Tesch, 1967; Pankhurst, 1982; Fontaine et al., 1995; Rohr et al., 2001). However, the correlation between the morphological changes and gonadal development is not clear. Svedäng and Wickström (1997) found that some female silver European eels (Anguilla anguilla), which were classified by visual inspection of the skin coloration, had low gonadosomatic index (GSI) similar to the yellow ones. In addition, the eye size in the European eel was positively correlated to gonadal development (Sbaihi et al., 2001), but this was not true in American eel (Anguilla rostrata) because of the variability of eye size (Han et al., in press; Vladykov, 1973).

This study aims to examine the correlation between skin coloration, gonadal maturation, and morphological characteristics of the eel during silvering and the biological significance of these changes. 


\section{Materials and methods}

\subsection{Specimen collection and classification}

A total of 217 Japanese eels were collected from eel traps in the lower reach of the Kaoping River in southwestern Taiwan $\left(120^{\circ} 50^{\prime} \mathrm{E}\right.$ and $\left.22^{\circ} 40^{\prime} \mathrm{N}\right)$ from November 1998 through November 2001. After collection, the eels were anesthetized by immersion in ice water. Total length (TL) and body weight (BW) of the eels were measured to the nearest 1 $\mathrm{mm}$ and $0.1 \mathrm{~g}$, respectively. Because the difference in size between left and right pectoral fins or eyes was not significant, the left pectoral fin $\left(L_{\mathrm{p}}, \pm 0.01 \mathrm{~mm}\right)$, and horizontal and vertical diameters $( \pm 0.01 \mathrm{~mm})$ of the left eye were measured. The weights of the liver $(\mathrm{LW}, \pm 0.01 \mathrm{~g})$ and gonad $(\mathrm{GW}, \pm 0.01 \mathrm{~g})$ of the eels were measured after killing the eels by decapitation. A subsample of 10 males and 72 females were randomly selected for measuring the weight of the digestive tract (DW, $\pm 0.01 \mathrm{~g}$ ). Sex was determined by histology. The monthly changes in the mean GSI of both sexes were examined from eels collected in the same months of different years because of small sample size. The females were divided by skin coloration pattern into three developmental stages: (1) yellow phase: the color of the eel was white/gray on the pectoral fins, green/gray on the back and yellow/ white on the belly; (2) silver phase: the eel was countershaded, with dark pigmentation on the back and pectoral fins, and silver/bronze on the belly; and (3) pre-silver phase: the eel was an intermediate type with gray/black on the pectoral fins and back and light silver/ bronze on the belly. The pre-silver phase was not found for males because of the small sample size; thus, males were only classified into yellow and silver phases.

\subsection{Calculation of morphometric indexes}

Five morphometric indexes were calculated.

The ocular index (OI) is a measure of eye area to total length of the eel (Pankhurst, 1982) and was calculated as follows:

$$
\mathrm{OI}=\left[((A+B) / 4)^{2} \times \pi / \mathrm{TL}\right] \times 100
$$

where $A$ and $B$ are horizontal and vertical diameters, respectively, of the left eye.

The fin-index (FI) was calculated as follows:

$$
\mathrm{FI}=\left[L_{\mathrm{p}} / \mathrm{TL}\right] \times 100
$$

The gonadosomatic index (GSI) was estimated as follows:

$$
\mathrm{GSI}=[\mathrm{GW} / \mathrm{BW}] \times 100
$$

The gut-index (GI) was estimated as follows:

$$
\mathrm{GI}=[\mathrm{DW} / \mathrm{BW}] \times 100
$$

The hepatosomatic index (HSI) was calculated as follows:

$$
\mathrm{HSI}=[\mathrm{LW} / \mathrm{BW}] \times 100
$$




\subsection{Examination of the maturity of the gonad}

The eel gonads were fixed with Bouin's solution, dehydrated in an ethanol series and embedded in paraffin, sectioned to $5 \mu \mathrm{m}$ thickness and then stained with hematoxylin and
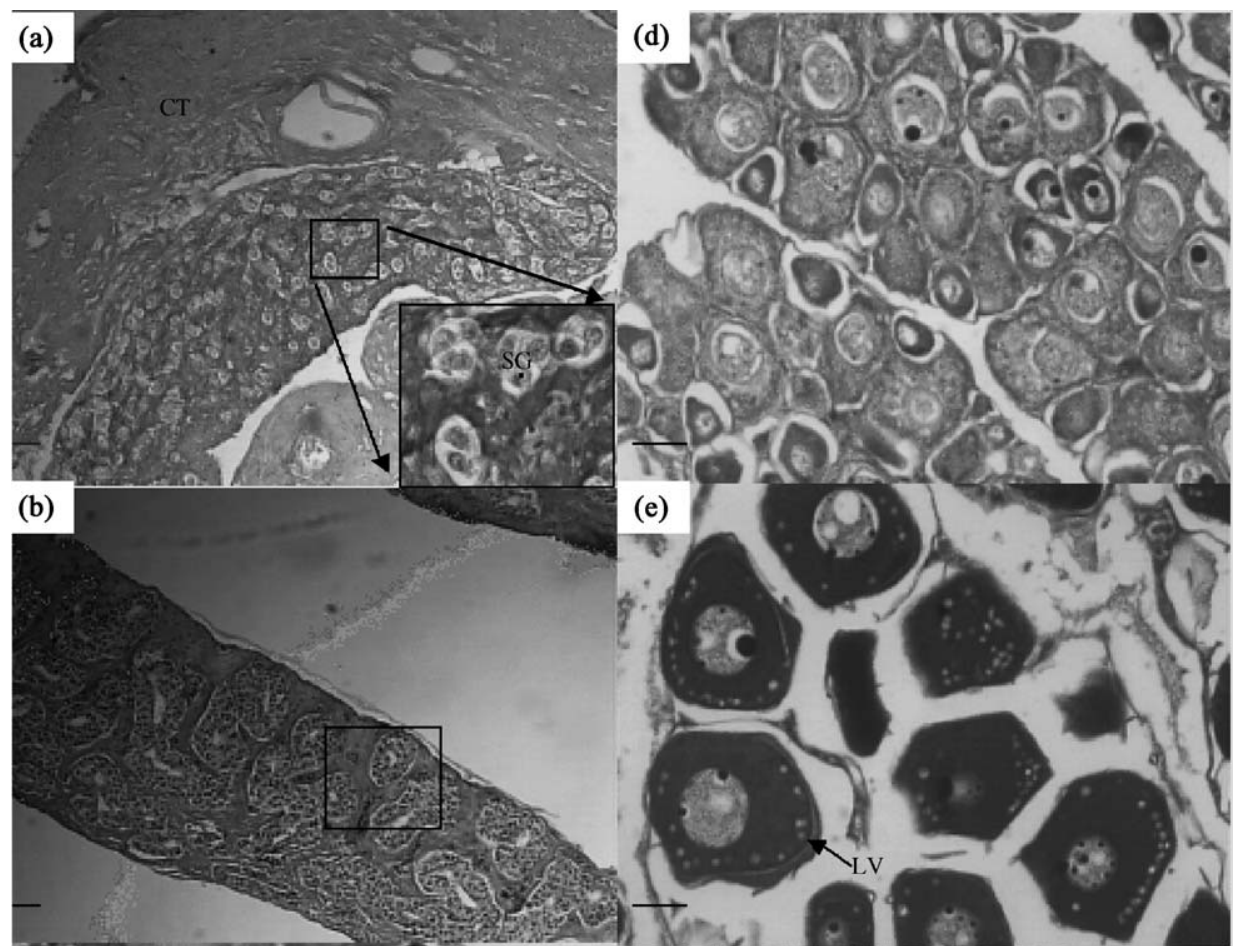

(c)

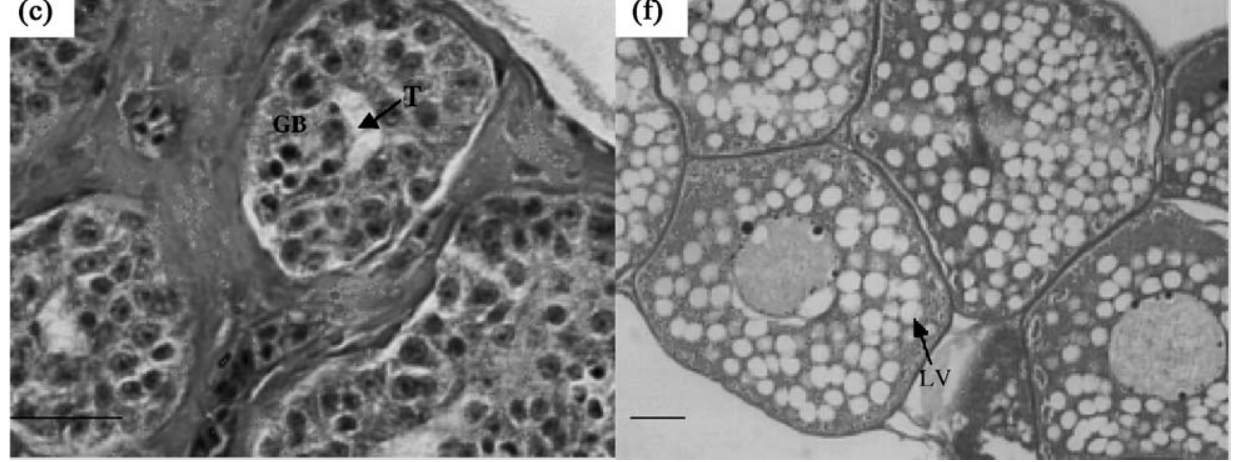

Fig. 1. Gonadal histology of the Japanese eel at different stages. (a) The testis of a yellow male: $44.1 \mathrm{~cm}$ TL, 95.1 g BW. Inset showed the enlarged spermatogonia. (b) The testis of a silver male: $67.5 \mathrm{~cm}$ TL, $334.2 \mathrm{~g} \mathrm{BW}$. (c) A magnification of indicated area in b. (d) The ovary of a yellow female: $43.4 \mathrm{~cm}$ TL, $111.2 \mathrm{~g} \mathrm{BW}$. (e) The ovary of a pre-silver female: $65.0 \mathrm{~cm} \mathrm{TL}, 332.0 \mathrm{~g} \mathrm{BW}$. (f) The ovary of a silver female: $64.8 \mathrm{~cm}$ TL, $442.8 \mathrm{~g} \mathrm{BW}$. Scale bar $=30 \mu \mathrm{m}$; SG: spermatogonia; GB: type B spermatogonia; CT: connective tissue; T: tubule; LV: lipid vesicles. 
Table 1

Morphometric and physiological indices of the Japanese eel among different developmental stages

\begin{tabular}{|c|c|c|c|c|c|c|}
\hline & Male & & Female & & & Difference in silver stage of \\
\hline & Yellow & Silver & Yellow & Pre-silver & Silver & mal \\
\hline $\mathrm{TL}(\mathrm{mm})$ & $\begin{array}{l}443.0 \pm 29.3 \\
(362-591,7)\end{array}$ & $\begin{array}{l}564.8 \pm 14.6 \\
(441-675,20)\end{array}$ & $\begin{array}{l}485.6 \pm 6.6 \\
(334-647,110)\end{array}$ & $\begin{array}{l}621.2 \pm 8.8 \\
(504-744,38)\end{array}$ & $\begin{array}{l}642.2 \pm 10.4 \\
(498-785,42)\end{array}$ & $\mathrm{M}<\mathrm{F}^{* * *}$ \\
\hline BW (g) & $\begin{array}{l}107.9 \pm 22.6 \\
(54.4-226.3,7)\end{array}$ & $\begin{array}{l}269.5 \pm 21.2 \\
(148.0-461.5,20)\end{array}$ & $\begin{array}{l}163.6 \pm 7.5 \\
(47.4-371.4,110)\end{array}$ & $\begin{array}{l}393.5 \pm 19.9 \\
(182.6-702.0,38)\end{array}$ & $\begin{array}{l}450.6 \pm 26.4 \\
(163.6-829.3,42)\end{array}$ & $\mathrm{M}<\mathrm{F}^{* * *}$ \\
\hline $\mathrm{OD}(\mu \mathrm{m})$ & - & - & $\begin{array}{l}63.95 \pm 1.19 \\
(25-90,110)\end{array}$ & $\begin{array}{l}102.71 \pm 1.71 \\
(90-130,38)\end{array}$ & $\begin{array}{l}159.27 \pm 4.28 \\
(130-225,42)\end{array}$ & \\
\hline GSI & $\begin{array}{l}0.07 \pm 0.02 \\
(0.01-0.12,7)\end{array}$ & $\begin{array}{l}0.15 \pm 0.01 \\
(0.06-0.25,20)\end{array}$ & $\begin{array}{l}0.27 \pm 0.01 \\
(0.02-0.73,110)\end{array}$ & $\begin{array}{l}0.55 \pm 0.03 \\
(0.24-0.85,38)\end{array}$ & $\begin{array}{l}1.32 \pm 0.07 \\
(0.55-2.43,42)\end{array}$ & $\mathrm{M}<\mathrm{F}^{* * *}$ \\
\hline OI & $\begin{array}{l}3.17 \pm 0.37 \\
(1.97-5.11,7)\end{array}$ & $\begin{array}{l}5.10 \pm 0.32 \\
(3.24-9.40,20)\end{array}$ & $\begin{array}{l}2.76 \pm 0.06 \\
(1.62-5.59,110)\end{array}$ & $\begin{array}{l}3.48 \pm 0.11 \\
(2.15-4.71,38)\end{array}$ & $\begin{array}{l}4.62 \pm 0.17 \\
(2.82-9.98,42)\end{array}$ & ns \\
\hline FI & $\begin{array}{l}4.27 \pm 0.21 \\
(3.49-5.13,7)\end{array}$ & $\begin{array}{l}5.19 \pm 0.12 \\
(4.09-6.07,20)\end{array}$ & $\begin{array}{l}4.00 \pm 0.04 \\
(3.33-5.23,110)\end{array}$ & $\begin{array}{l}4.37 \pm 0.06 \\
(3.82-5.10,38)\end{array}$ & $\begin{array}{l}4.84 \pm 0.08 \\
(3.88-6.08,42)\end{array}$ & ns \\
\hline GI & $\begin{array}{l}1.48 \pm 0.08 \\
(1.40-1.56,2)\end{array}$ & $\begin{array}{l}0.49 \pm 0.07 \\
(0.25-0.85,8)\end{array}$ & $\begin{array}{l}1.65 \pm 0.07 \\
(1.05-2.63,31)\end{array}$ & $\begin{array}{l}1.48 \pm 0.07 \\
(0.91-2.30,24)\end{array}$ & $\begin{array}{l}0.56 \pm 0.06 \\
(0.24-1.03,17)\end{array}$ & ns \\
\hline HSI & $\begin{array}{l}1.17 \pm 0.09 \\
(0.94-1.63,7)\end{array}$ & $\begin{array}{l}1.29 \pm 0.06 \\
(0.99-2.17,20)\end{array}$ & $\begin{array}{l}1.11 \pm 0.03 \\
(0.47-1.90,110)\end{array}$ & $\begin{array}{l}1.09 \pm 0.03 \\
(0.71-1.44,38)\end{array}$ & $\begin{array}{l}1.18 \pm 0.05 \\
(0.73-2.12,42)\end{array}$ & ns \\
\hline
\end{tabular}

Upper row: mean \pm S.E.; lower row: range and sample size. Significance level: $* * * p<0.001$; ns, not significant.

Abbreviation: TL: total length; BW: body weight; OD: oocyte diameter; GSI: gonadosomatic index; OI: ocular index; FI: fin-index; GI: gut-index; HSI: hepatosomatic index. 
eosin. The mean oocyte diameter (OD, $\pm 1 \mu \mathrm{m})$ of the ovary was estimated from 20 randomly selected, maximum-sized oocytes with complete nucleus. Maturation stages of the oocytes and spermatogonia were determined according to Yamamoto et al. (1974) and Miura et al. (1991).

\subsection{Data analysis}

To eliminate the effect of TL on the significance test of the morphometric indexes among stages, the indexes and TL of the eel were logarithmically normalized, and the residuals of the regression of GSI, OI, HSI, FI, and GI on TL were calculated according to Jakob et al. (1996) with the equation:

$$
\ln (\operatorname{Index})=\mathrm{a} \times \ln (\mathrm{TL})+\mathrm{b}+R_{\operatorname{Index}}
$$

where $R_{\text {Index }}$ was the residual.

Significance test of the differences in mean indices (GSI, OI, FI, GI, and HSI) and the residuals of these indexes among developmental stages were conducted respectively with Student's $t$-test for males and with Tukey's HSD multiple-comparison test for females (Winer, 1971). The significance test of the correlation coefficients among indices was conducted by the Kendall rank correlation (Siegel, 1956).

\section{Results}

\subsection{Gonadal development of males}

The gonads of yellow males had transparent threads with deeper notches dividing the gonad into lobes. The nests of germ cells in the testes contained only a few (usually 1-4)

Table 2

Comparison of mean indices (GSI, OI, FI, GI, and HSI) and the residuals of the regression of the indices on total length of the Japanese eel among stages by Student's $t$-test for males and by Tukey's HSD multiple-comparison test for females

\begin{tabular}{|c|c|c|c|c|c|}
\hline & \multicolumn{5}{|l|}{ Male } \\
\hline & GSI & OI & FI & GI & HSI \\
\hline Mean & $\mathrm{Y}<\mathrm{S} * * *$ & $\mathrm{Y}<\mathrm{S} * *$ & $\mathrm{Y}<\mathrm{S} * * *$ & $\mathrm{Y}>\mathrm{S} * * *$ & $\mathrm{Y}=\mathrm{S}$ \\
\hline \multirow[t]{3}{*}{ Residuals } & $\mathrm{Y}<\mathrm{S}^{*}$ & $\mathrm{Y}=\mathrm{S}$ & $\mathrm{Y}=\mathrm{S}$ & $\mathrm{Y}=\mathrm{S}$ & $\mathrm{Y}=\mathrm{S}$ \\
\hline & \multicolumn{5}{|l|}{ Female } \\
\hline & GSI & OI & FI & GI & HSI \\
\hline Mean & $\mathrm{Y}<\mathrm{PS}^{* * *}<\mathrm{S} * * *$ & $\mathrm{Y}<\mathrm{PS}^{* * *}<\mathrm{S} * * *$ & $\mathrm{Y}<\mathrm{PS}^{* * *}<\mathrm{S}^{* * *}$ & $\mathrm{Y}=\mathrm{PS}>\mathrm{S} * * *$ & $\mathrm{Y}=\mathrm{Ps}=\mathrm{S}$ \\
\hline Residuals & $\mathrm{Y}=\mathrm{Ps}<\mathrm{S} * * *$ & $\mathrm{Y}=\mathrm{Ps}<\mathrm{S}^{* * *}$ & $\mathrm{Y}=\mathrm{Ps}<\mathrm{S} * * *$ & $\mathrm{Y}=\mathrm{Ps}>\mathrm{S} * * *$ & $\mathrm{Y}=\mathrm{Ps}=\mathrm{S}$ \\
\hline
\end{tabular}

Abbreviation for developmental stages: Y, yellow stage; Ps, pre-silver stage; S, silver stage. Significance levels: $* p<0.05 ; * * p<0.01 ; * * * p<0.001$ 
spermatogonia which were at the type A or early type B stage (Fig. 1a) [according to terminology proposed for the Japanese eel by Miura et al. (1991)]. No lumina were found in the nests. In the silver males, the spermatogonia were mainly in the late type B stage due

\section{(a)}

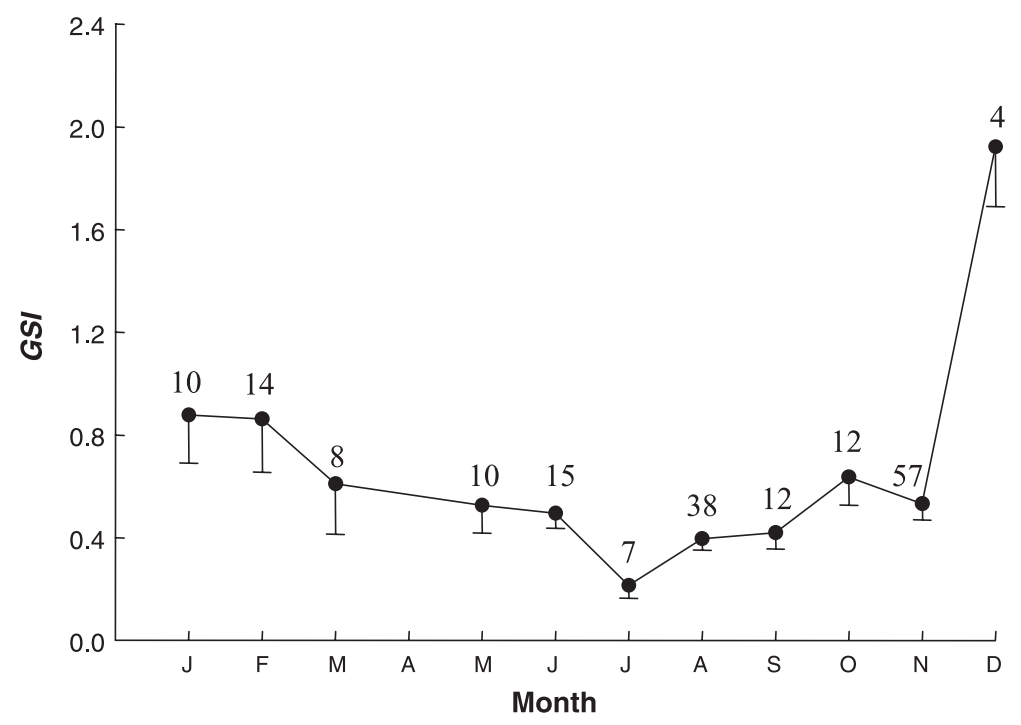

(b)

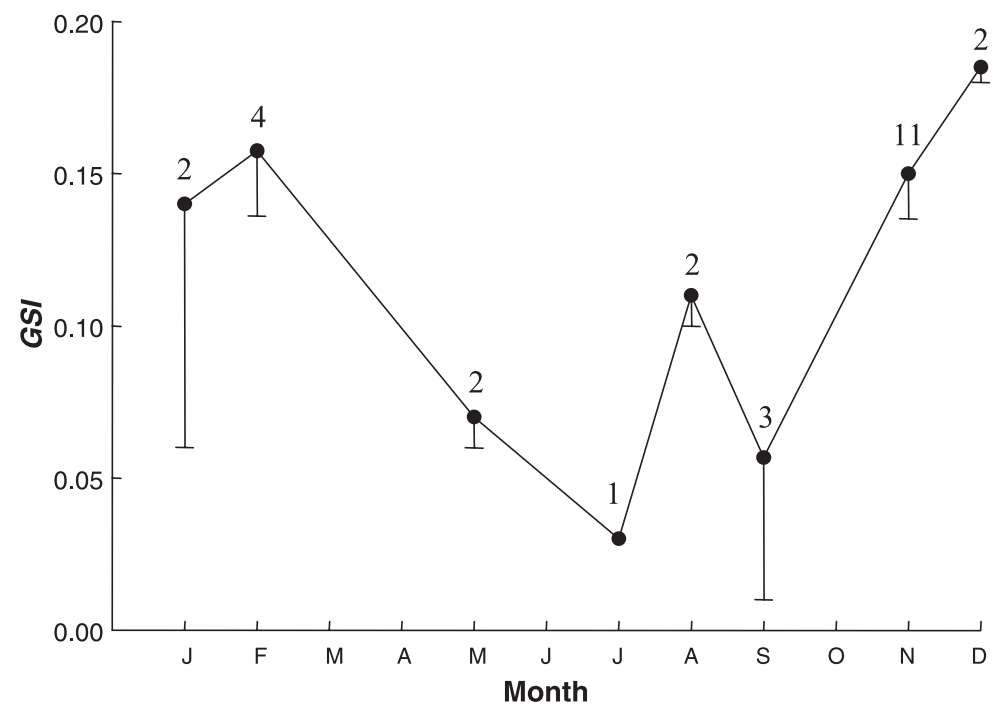

Fig. 2. Monthly changes in the mean GSI ( \pm S.E.) of females (a) and males (b). Numerals above indicate sample size. 
(a)

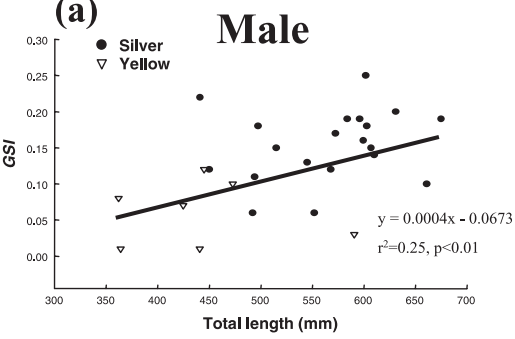

(c)

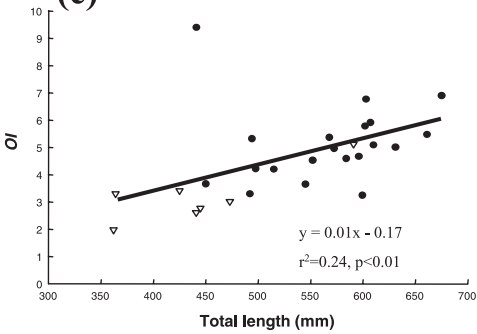

${ }_{7.0}$ (e)

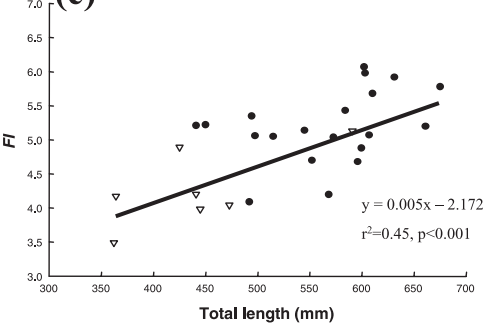

(g)

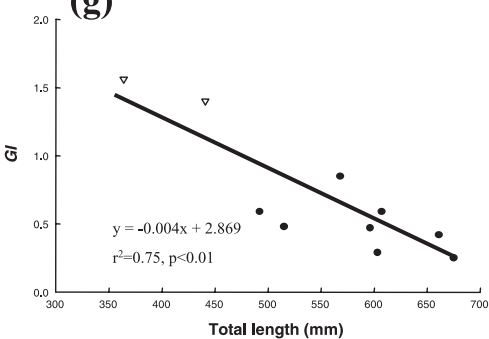

(i)

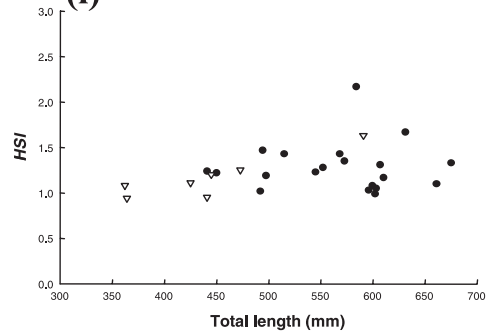

(b)

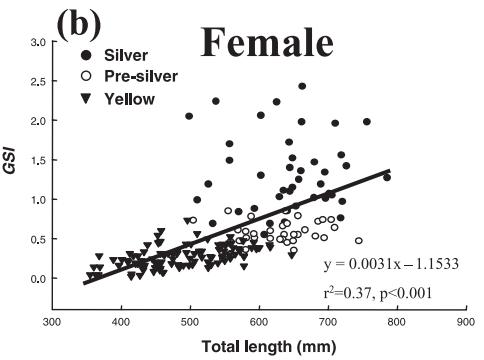

(d)
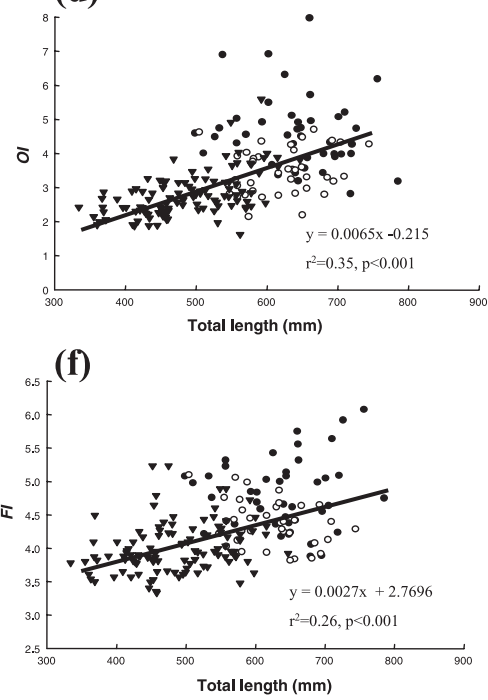

(h)
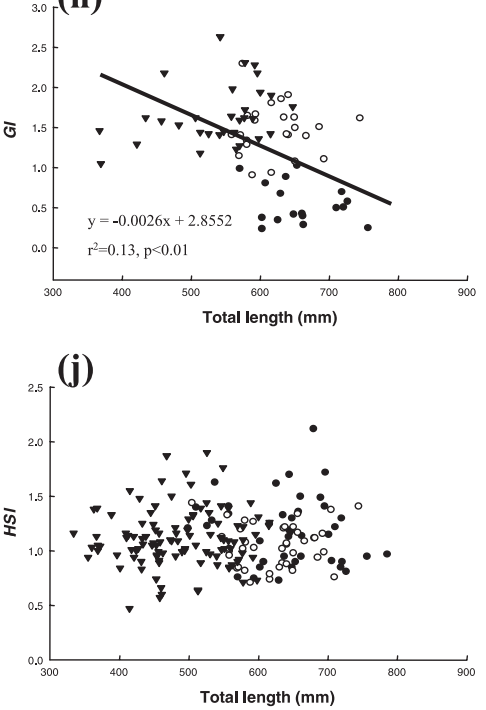
Table 3

Significance tests of the correlation coefficients among GSI, OI, FI, GI, and HSI for male (upper) and female (lower) Japanese eels

\begin{tabular}{lccccr}
\hline & GSI & OI & FI & GI & HSI \\
\hline GSI & - & $0.40^{* *}$ & $0.43^{* *}$ & $-0.67^{* *}$ & 0.15 \\
OI & $0.57^{* * *}$ & - & $0.55^{* * *}$ & $-0.66^{* *}$ & 0.22 \\
FI & $0.45^{* * *}$ & $0.48^{* * *}$ & - & $-0.66^{* *}$ & 0.22 \\
GI & $-0.48^{* * *}$ & $-0.29 * * *$ & $-0.26^{* *}$ & - & -0.34 \\
HSI & 0.03 & 0.07 & 0.04 & 0.21 & - \\
\hline
\end{tabular}

Significance levels: ${ }^{*} p<0.05 ; * * p<0.01 ;{ }^{* * *} p<0.001$.

to their smaller size and greater number (Fig. 1b). The nest obviously formed tubules with clear lumina (Fig. 1c). More advanced spermatocytes, spermatids, or spermatozoa were not found. The mean ( \pm S.E.) GSI also significantly increased from $0.07 \pm 0.02$ in the yellow eel to $0.15 \pm 0.01$ in the silver eel (Table 1$)$.

\subsection{Gonadal development of females}

Oocytes of the ovaries of yellow females were mainly in stage II (chromatin nucleolus stage) (Fig. 1d). Oocytes in the pre-silver phase grew rapidly with a round nucleus and one large and some small nucleoli near the nuclear envelopes (Fig. 1e), mainly at stage III (perinucleolus stage). Meanwhile, lipid vesicles became apparent in the periphery of the oocyte (arrow in Fig. 1e). Oocytes grew continuously in the silver phase and oil drops accumulated gradually from the periphery towards the nucleus and finally filled the whole cytoplasm (Fig. 1f) at stage IV (oil-drop stage). Some larger oocytes in the silver phase may have entered stage V (primary yolk globule stage) but more advanced stages were not found. The mean ( \pm S.E.) GSI of females significantly increased from $0.27 \pm 0.01$ in the yellow eel phase to $0.55 \pm 0.03$ in the pre-silver and to $1.32 \pm 0.07$ in the silver phase (Tables 1 and 2). Similarly, the mean OD also significantly increased from $63.95 \pm 1.19 \mu \mathrm{m}$ for yellow eels to $102.71 \pm 1.71 \mu \mathrm{m}$ in pre-silver and $159.27 \pm 4.28 \mu \mathrm{m}$ in silver phase eels (Tables 1 and $2)$. The OD was highly correlated with the GSI $(r=0.91, p<0.001)$. The mean GSI of the silver phase eel was significantly higher for females than for males $(p<0.001)$ (Table 1$)$. In addition, the female reached the silver phase at a larger length and weight $(642.2 \pm 10.4$ $\mathrm{mm}, 450.6 \pm 26.4 \mathrm{~g})$ than the male $(564.8 \pm 14.6 \mathrm{~mm}, 269.5 \pm 21.2 \mathrm{~g})$ (Table 1).

\subsection{Monthly changes of GSI}

The sex ratio of the eel population in the Kaoping River was strongly skewed towards females, which constituted $87.6 \%$ of the 217 sex-determined eels ( 27 males versus 190 females) (Table 1). The monthly changes in the mean GSI of both sexes are shown in Fig. 2. The mean GSI of females was higher in the period from late autumn to winter

Fig. 3. Linear regressions of GSI (a, b), OI (c, d), FI (e, f), GI (g, h), and HSI (i, j) on total length of the males and females, respectively. Solid circle: silver eel; open circle: pre-silver female; filled triangle: yellow female; open triangle: yellow male. 
(a)

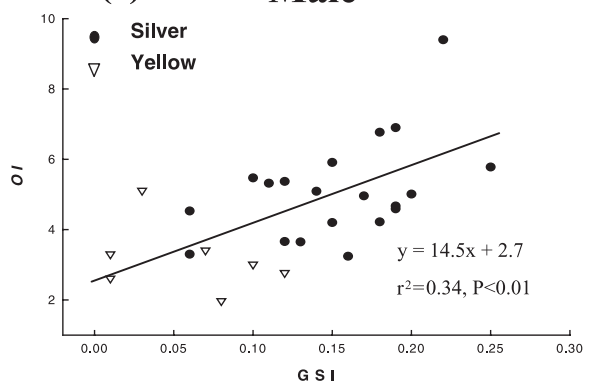

(c)

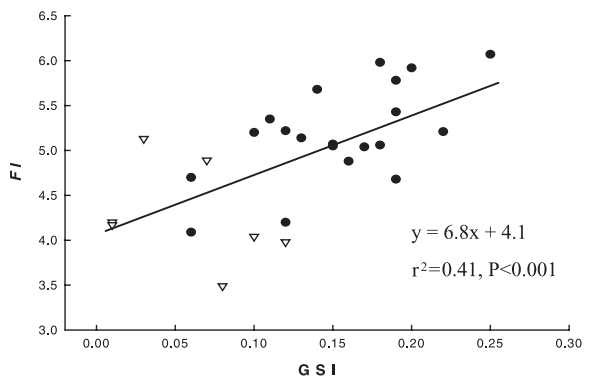

(e)

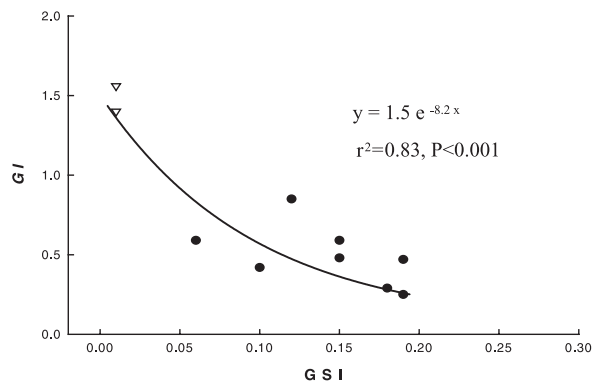

(g)

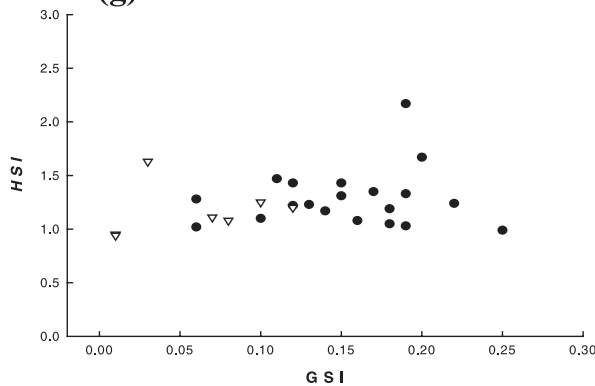

(b)

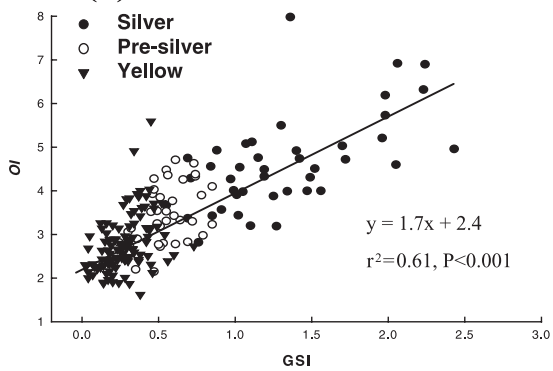

(d)

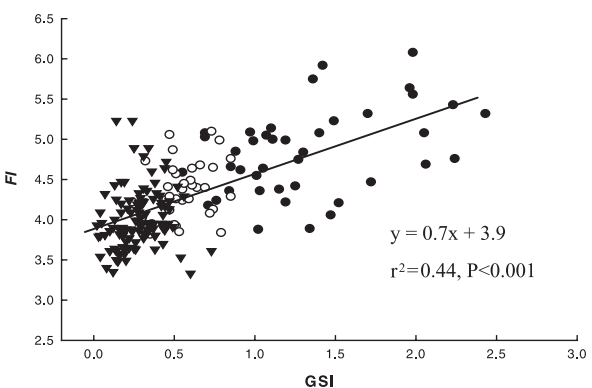

(f)

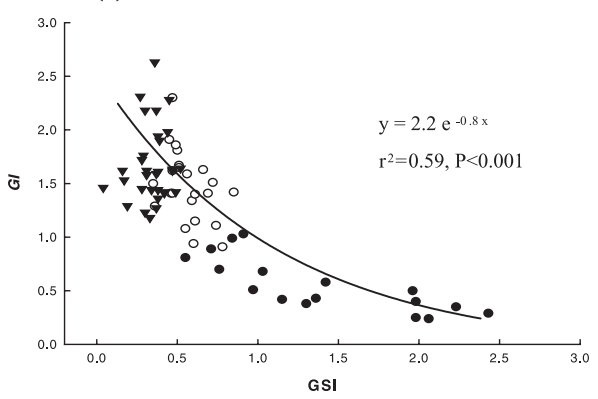

(h)

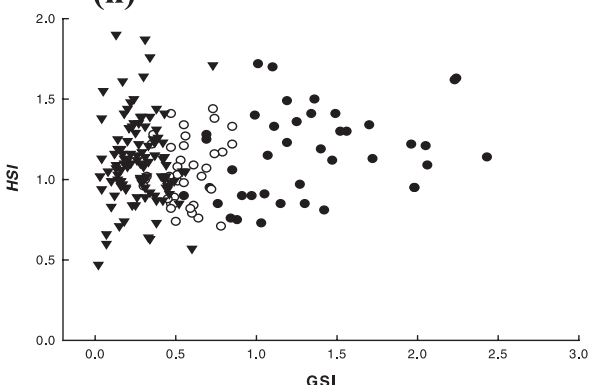

Fig. 4. Linear regressions of OI (a, b), FI (c, d), GI (e, f), and HSI (g, h) on GSI of the male and female. Solid circle: silver eel; open circle: pre-silver female; filled triangle: yellow female; open triangle: yellow male. 
(October-February) (Fig. 2a) because of the occurrence of silver females, which had more advanced development of the gonads (Table 1). The pre-silver females, on the other hand, were dominant in the summer and autumn (May-September) and yellow females occurred all year around. The monthly changes in the mean GSI of males were similar to those of females, lowest in July and gradually increasing to a maximum in December (Fig. 2a,b).

\subsection{Variation of morphometric indexes with growth}

The GSI, OI, and FI versus TL were significantly positively correlated and GI versus TL was negatively correlated for both sexes (Fig. 3a-h). However, the correlation between GI and TL was not significant in yellow females $(p>0.05)$. Also, the correlation between HSI and TL was not significant, irrespective of the sexes and stages (Fig. 3i,j). This indicated that the indices of GSI, OI, and FI increased with fish growth and the GI decreased after the yellow phase, while the HSI was constant through all phases of both sexes.

\subsection{Comparison of morphometric indexes among stages}

The mean GSI, OI, and FI were all significantly larger in silver than pre-silver and yellow phase eels. GI was significantly smaller in the silver than yellow phase eels (Table 2). On the other hand, the residuals of the regression of GSI, OI, HSI, FI, and GI on TL among developmental phases were still significantly different in the silver females and GSI of silver males, indicating that the differences of mean indices among phases were affected by a factor other than total length (Table 2). This discrepancy in significance between mean and residual of the indices may be due to the fact that the GSI, OI, and FI increased and the alimentary tract shrank rapidly during the silver phase. The difference in HSI among stages was not significant in either mean or residuals (Table 2).

The relationships among GSI, OI, FI, and GI of both sexes were moderately to highly correlated except HSI (Table 3). The regressions of OI, and FI on GSI were linearly related in males (Fig. 4a,c) and females (Fig. 4b,d). The regressions of GI on GSI for both sexes were negatively exponentially related (Fig. 4e,f). This indicated that the OI, FI, and GI, but not the HSI, could be used to evaluate the maturity of the eel.

\section{Discussion}

In the European eel, the dark color on the back is believed to be a result of the increase in the concentration of light-absorbing melanin and the decrease of reflecting materials in the skin, while the bright color on the belly of the eel may be due to the decreased number of melanophores in the skin (Pankhurst and Lythgoe, 1982). Thus, the aggregation or dispersal of the melanosomes in the skin may change skin color. Alternatively, the dispersal of purines in the skin might be correlated with maturation, causing a silver color on the belly (Pankhurst and Lythgoe, 1982). We found that changes in the skin color of Japanese eels were highly correlated with gonadal development. Thus, the countershading coloration of the silvering eel was probably a physiological modification, which could be used as a criterion to assess the sexual maturity of Japanese eel. 
The residuals of the regressions of GSI, OI, and FI on TL of females were larger in silver phase than other phases (Fig. 3b,d,f), indicating that the relative growth of GSI, OI, and FI versus TL was allometric, i.e., the development of females in the silver phase may remodel their body's organization for reproduction rather than growth. The remodeling of silver phase females was also discernible from the intense shrinkage of the digestive tract (Fig. 3h). Conversely, the residuals were not significant for the male except for the GSI (Fig. 3a,c,e). One possible explanation is that the silver males might not have reached their maximum size and were still growing. However, the shrinkage of the digestive tract in males was as great as for the silver phase females (Fig. 3g), indicating that further growth for silver phase males was unlikely. Therefore, the lack of significances between residuals of different developmental phases in males was more likely due to the low sample size.

The difference in residuals of the regression of GSI on TL for the female between silver and other phases was larger than males (Table 2). The limited testicular development of silver phase males in the rivers indicates that they were still at a premature stage. Artificial propagation experiments indicated that the progress of spermatogenesis was faster than that of oogenesis after gonadotropin treatment (Ohta et al., 1997). Thus, to obtain simultaneous maturation between sexes, it would be necessary to initiate treatment of males later than females. In addition, the low gonadal developments of silver phase eels indicates that the silvering is more a preparation for migration than maturation.

The modification of external morphology of the silver phase eel has been proposed to be a preparation for the adaptation to the marine environment before their spawning migration (Pankhurst, 1982; Fontaine et al., 1995). The countershading skin color of the silver eel could be a camouflage in marine light conditions (Tesch, 1977). The enlargement of the pectoral fins can improve swimming performance (Rohr et al., 2001) and the increased eye size may be an adaptive response to deep marine environments with dim light, similar to those observed in mesopelagic fishes (Pankhurst and Lythgoe, 1983). The degeneration of the digestive tract during silvering may be a trade-off to preserve energy and space for the gonadal development. The gonadal and morphological changes preparatory to the spawning migration are necessarily coupled by endocrine mechanisms.

In Anguilla australis, injection of androgen (11-ketotestosterone) into females was found to cause morphological changes, such as chisel-shaped snouts, black and large pectoral fins, enlarged eyes, livers, and gonads (Rohr et al., 2001). In addition, the injection of human chorionic gonadotropin (HCG) simultaneously induced the development of gonads and the degeneration of the alimentary tract in the European eel (Pankhurst and Sorensen, 1984). In the Japanese eel, broad expressions of androgen receptors in the gill, heart, head kidney, spleen, liver, muscle, brain, testis, and ovary were also found (Ikeuchi et al., 1999). This inferred the possible effect of androgen on these tissues. Accordingly, the synchronous changes in gonadal development and morphological characteristics are probably hormone-related. Our studies on the linear regression of the OI, FI, and GI on GSI indicated that eels with larger OI and FI, and lower GI are more mature. In addition, the eyes, pectoral fins, and digestive tracts were modified further following the developments of the gonads. This phenomenon has been verified by artificial propagation experiments, the maximum OI and GSI can be over 10 and 40 in silvering female European eels (Boëtius and Boëtius, 1980), and the maximum GSI can 
reach 3 in silvering male Japanese eels (Ohta et al., 1997). On the other hand, the mean HSI did not change significantly during silvering in both sexes (Table 2; Fig. 3i,j), similar to those of American eels (Lewander et al., 1974) and European eels (Sbaihi et al., 2001). In $A$. australis, however, 11-ketotestosterone stimulated the liver and gonadal development of the females (Rohr et al., 2001), which was attributed to the effect of vitellogenesis in the oocytes. In pre-silver and silver female Japanese eels, although the deposition of oildroplets was actively in progress, the oocytes were mainly in the peri-nucleolus or oil-drop stage. The accumulation of vitellogenin was not yet significant. This might explain why there were no significant differences in HSI among developmental stages.

In conclusion, our results indicate that skin color changed synchronously with gonadal development, and the OI, FI, and GI also changed synchronously with GSI during silvering of the Japanese eel. Therefore, external morphological characteristics such as skin coloration, OI, and FI are reliable indicators of the maturation of Japanese eel, and can be used as maturity-selecting criteria for the selection of eels for artificial propagation.

\section{Acknowledgements}

This study was financially supported by the National Science Council, Taiwan, ROC (NSC 89-2313-B056-008), and the Council of Agriculture, Executive Yuan, Taiwan, ROC (90AS-1.4.5-FA-F1-36). The authors are grateful to Mr. Brian M. Jessop for the critical review on the manuscript.

\section{References}

Boëtius, I., Boëtius, J., 1980. Experimental maturation of female silver eels, Anguilla anguilla: estimates of fecundity and energy reserves for migration and spawning. Dana 1, 1-28.

Ege, V., 1939. A revision of the genus Anguilla Shaw, a systematic, phylogenetic and geographical study. Dana Report 16, 1-256.

Fontaine, Y.A., Pisam, M., Moal, C.L., Rambourg, A., 1995. Silvering and gill 'mitochondria-rich' cells in the eel, Anguilla anguilla. Cell and Tissue Research 281, 465-471.

Han, Y.S., Yu, C.H., Yu, H.T., Chang, C.W., Liao, I.C., Tzeng, W.N., 2002. The exotic American eel in Taiwan: ecological implications. Journal of Fish Biology 60 (6), 1608-1612.

Ijiri, S., Kayaba, T., Takeda, N., Tachiki, H., Adachi, S., Yamauchi, K., 1998. Pretreatment reproductive stage and oocyte development induced by salmon pituitary homogenate in the Japanese eel, Anguilla japonica. Fishery Science 64, 531-537.

Ikeuchi, T., Todo, T., Kobayashi, T., Nagahama, Y., 1999. cDNA cloning of a novel androgen receptor subtype. Journal of Biological Chemistry 274, 25205-25209.

Jakob, E.M., Marshall, S.D., Uetz, G.W., 1996. Estimating fitness: a comparison of body condition indices. Oikos $77,61-67$.

Jessop, B.M., 1987. Migrating American eels in Nova Scotia. Transactions of the American Fisheries Society $116,161-170$.

Lewander, K., David, G., Johansson, M.-L., Larsson, A., Lidman, U., 1974. Metabolic and hematological studies on the yellow and silver phases of the European eel, Anguilla anguilla L.: I. Carbohydrate, lipid, protein and inorganic ion metabolism. Comparative and Biochemical Physiology 47B, 571-581.

Liao, I.C., Kuo, C.L., Tzeng, W.N., Hwang, S.T., Wu, C.L., Wang, C.H., Wang, Y.T., 1996. The first time of leptocephali of Japanese eel Anguilla japonica collected by Taiwanese researchers. Journal of Taiwan Fisheries Research 4, 107-116. 
Liao, I.C., Liau, S.G., Tzeng, W.N., Kuo, C.L., 1999. Investigation on Anguilla japonica leptocephali by Fisheries Researcher 1. In: Aida, K., Tsukamoto, K. (Eds.), Studies on the Life Cycle of Eel. Kaiyo Monthly Special Issue, vol. 18, pp. 27-33. In Japanese.

Matsui, I., 1958. On the record of a leptocephalus and catadromous eels of Anguilla japonica in the waters around Japan with a presumption of their spawning places. Journal of the Shimonoseki College of Fisheries 7 , 151-167.

Matsui, I., 1972. Unagigaku: Eel Biology. Kosei-sha Kosei-Kaku, Tokyo.

Miura, T., Yamauchi, K., Takahashi, H., Nagahama, Y., 1991. Hormonal induction of all stages of spermatogenesis in vitro in the male Japanese eel (Anguilla japonica). Proceedings of the National Academy of Sciences of the United States of America 88, 5774-5778.

Ohta, H., Kagawa, H., Tanaka, H., Okuzawa, K., Iinuma, N., Hirose, K., 1997. Artificial induction of maturation and fertilization in the Japanese eel, Anguilla japonica. Fish Physiology and Biochemistry 17, $163-169$.

Pankhurst, N.W., 1982. Relation of visual changes to the onset of sexual maturation in the European eel Anguilla anguilla (L.). Journal of Fish Biology 21, 127-140.

Pankhurst, N.W., Lythgoe, J.N., 1982. Structure and colour of the integument of the European eel Anguilla anguilla (L.). Journal of Fish Biology 21, 279-296.

Pankhurst, N.W., Lythgoe, J.N., 1983. Changes in vision and olfaction during sexual maturation in the European eel Anguilla anguilla (L.). Journal of Fish Biology 23, 229-240.

Pankhurst, N.W., Sorensen, P.W., 1984. Degeneration of the alimentary tract in sexually maturing European Anguilla anguilla (L.) and American eel Anguilla rostrata (Le Sueur). Canadian Journal of Zoology 62, $1143-1149$

Rohr, D.H., Lokman, P.M., Davie, P.S., Young, G., 2001. 11-Ketotestosterone induces silvering-related changes in immature female short-finned eels, Anguilla australis. Comparative Biochemistry and Physiology 130 A, $701-714$

Sbaihi, M., Fouchereau-Peron, M., Meunier, F., Elie, P., Mayer, I., Burzawa-Gerard, E., Vidal, B., Dufour, S., 2001. Reproductive biology of the conger eel from the south coast of Brittany, France and comparison with the European eel. Journal of Fish Biology 59, 302-318.

Siegel, S., 1956. Nonparametric statistics for the behavioral sciences. McGraw-Hill, New York.

Sorensen, P.W., Pankhurst, N.W., 1988. Histological changes in the gonad, skin, intestine and olfactory epithelium of artificially-matured male American eels, Anguilla rostrata (Le Sueur). Journal of Fish Biology 32, $297-307$.

Svedäng, H., Wickström, H., 1997. Low fat contents in females silver eels: indications of insufficient energetic stores for migration and gonadal development. Journal of Fish Biology 50, 475-486.

Tesch, F.W., 1967. Homing of eels (Anguilla anguilla) in the southern North Sea. Marine Biology (Berlin) I, 1-9.

Tesch, F.W., 1977. The Eel. Biology and Management of Anguillid Eels. Chapman \& Hall, London.

Tsukamoto, K., 1992. Discovery of the spawning area for Japanese eel. Nature 356, 789-791.

Tzeng, W.N., 1985. Immigration timing and activity rhythms of the eel, Anguilla japonica, elvers in the estuary of northern Taiwan, with emphasis on environmental influences. Bulletin of Japanese Society of Fishery Oceanography 47/48, 11-28.

Tzeng, W.N., 1996. Short- and long-term fluctuations in catches of elvers of the Japanese eel, Anguilla japonica. In: Hancock, D.A., Smith, D.C., Grant, A., Beumer, J.B. (Eds.), Developing and Sustaining World Fisheries Resources: The State of Science and Management. 2nd World Fisheries Compress Proceedings. CSIRO Publishing, Victoria, Australia, pp. 85-89.

Tzeng, W.N., Lin, H.R., Wang, C.H., Xu, S.N., 2000. Differences in size and growth rates of male and female migrating Japanese eels in Pearl River, China. Journal of Fish Biology 57, 1245-1253.

Vladykov, V.D., 1973. Macrophthalmia in the American eel (Anguilla rostrata). Journal of the Fisheries Research Board of Canada 30, 689-693.

Waring, H., 1963. Colour Change Mechanisms of Cold-Blooded Vertebrates. Academic Press, New York, p. 266.

Winer, B., 1971. Statistical Principles in Experimental Design. McGraw-Hill, New York.

Yamamoto, K., Yamauchi, K., 1974. Sexual maturation of Japanese eel and production of eel larvae in the aquarium. Nature 1251, 220-222.

Yamamoto, K., Oomori, M., Yamauchi, K., 1974. Oogenesis of the Japanese eel. Bulletin of the Japanese Society of Scientific Fisheries 40, 9-15. 